Disclosure of Interest: None declared

DOI: 10.1136/annrheumdis-2017-eular.2454

\section{SAT0069 A RAPID3-LIKE INDEX DOCUMENTS SUPERIOR EFFICACY OF BARICITINIB TO ADALIMUMAB AND PLACEBO, SIMILAR TO DAS28 AND CDAI IN THE RA-BEAM CLINICAL TRIAL IN PATIENTS WITH RHEUMATOID ARTHRITIS}

T. Pincus $^{1}$, B. Zhu ${ }^{2}$, C.J. Larmore ${ }^{2}$, J.D. Bradley ${ }^{2}$, N. Patel ${ }^{2}$, C.L. Gaich ${ }^{2}$, A.E. Koch ${ }^{2} .{ }^{1}$ Rush University Medical Center, Chicago; ${ }^{2}$ Eli Lilly and Company, Indianapolis, United States

Background: RAPID3 (Routine Assessment of Patient Index Data) indicates differences in efficacy of active versus control treatments at levels similar to DAS28-ESR (Disease Activity Score 28-Erythrocyte Sedimentation Rate) and CDAI (Clinical Disease Activity Index) in clinical trials of adalimumab, abatacept, certolizumab.

Objectives: To compare improvement according to RAPID3, DAS 28-ESR, and CDAl in the RA-BEAM trial of baricitinib vs adalimumab and placebo.

Methods: Post-hoc analyses were performed of the RA-BEAM trial, in which patients with moderately to severely active rheumatoid arthritis and an inadequate response to methotrexate (MTX) were randomized to baricitinib, adalimumab, or placebo. All patients were to continue stable background MTX and other DMARDs, as well as stable low-dose prednisone and/or NSAIDs, if indicated. A RAPID3-like index was computed from 3 measures: physical function (FN), pain (PN), and patient global assessment (PATGL). FN on a HAQ (Health Assessment Questionnaire) of 20 items [rather than MDHAQ (multidimensional HAQ) of 10 items] was recalculated from $0-3$ to $0-10 ; \mathrm{PN}$ and PATGL (visual analog scales) were recalculated from 0-100 to 0-10, for a 0-30 total score, hence "RAPID3-like". Mean values at baseline and Week 24 for RAPID3-like, DAS28-ESR, and CDAI, and percent change from baseline were computed in the 3 treatment groups. The proportion of patients with high/moderate activity/severity at Week 24 versus low activity/severity/remission, as well as correlations of the 3 indices at Week 24, were calculated. Statistical significance for percent change was analyzed using Wilcoxon tests, after imputation of missing values using modified last observation carried forward (mLOCF); low activity/severity/remission was compared between groups using a logistic model, adjusting for region and baseline joint erosion status after imputation of missing values using non-responder imputation.

Results: Improvement from baseline to Week 24 ranged from $19.2 \%$ to $37.0 \%$ in placebo patients, $40.0 \%$ to $65.9 \%$ in baricitinib-treated patients, and $37.6 \%$ to $60.9 \%$ in adalimumab-treated patients (Table), least in DAS28-ESR, intermediate in RAPID3-like, and highest in CDAI. Changes according to RAPID3-like, DAS28ESR and CDAI were similar in the 3 treatment groups; baricitinib and adalimumab were superior to placebo according to all indices, and baricitinib was superior to adalimumab according to RAPID3-like and CDAI (Table). Correlations of RAPID3like with DAS28-ESR and CDAl ranged from $r=0.61$ to 0.75 and for DAS28-ESR with CDAl from $r=0.86$ to 0.91 (all $p<0.001$ ). The proportion of patients with low activity/severity/remission at Week 24 ranged from $9.6 \%$ to $19.7 \%$ in placebo patients, $31.6 \%$ to $49.9 \%$ in baricitinib-treated patients, and $33.6 \%$ to $47.6 \%$ in adalimumab-treated patients. RAPID3-like results were intermediate between DAS28-ESR and CDAI.

\begin{tabular}{|c|c|c|c|c|c|c|c|c|}
\hline & & \multirow[b]{2}{*}{$\begin{array}{c}\text { Baseline } \\
\text { Mean }\end{array}$} & \multirow[b]{2}{*}{$\begin{array}{c}\text { Week } 24 \\
\text { Mean }\end{array}$} & \multirow{2}{*}{$\begin{array}{c}\text { Week } 24 \\
\% \text { Change } \\
\text { from Baseline }\end{array}$} & \multirow[b]{2}{*}{$\begin{array}{l}\text { Correlation with } \\
\text { DAS28.ESR }\end{array}$} & \multirow[b]{2}{*}{$\begin{array}{c}\text { Correlation } \\
\text { with CDAI }\end{array}$} & \multirow{2}{*}{$\begin{array}{c}\text { High or Mod } \\
\text { at Week } 24 \\
\text { n (\%) }\end{array}$} & \multirow{2}{*}{$\begin{array}{c}\text { Low or } \\
\text { Remission } \\
\text { at Week } 24 \\
\mathrm{n}(\%)\end{array}$} \\
\hline & & & & & & & & \\
\hline \multirow{4}{*}{ RAPID3-like } & $\begin{array}{l}\text { Placebo } \\
(\mathrm{N}=488)\end{array}$ & 17.2 & 12.7 & $-22.5 \%$ & 0.69 & 0.61 & $399(81.8 \%)$ & $89(18.2 \%)$ \\
\hline & $\begin{array}{l}\text { Baricitinib } \\
(\mathrm{N}=487)\end{array}$ & 17.7 & 8.4 & $-51.0 \% " \cdots \neq \neq$ & 0.67 & 0.63 & $266(54.6 \%)$ & $221(45.4 \%)^{\cdots \cdots \neq \neq}$ \\
\hline & $\begin{array}{l}\text { Adalimumab } \\
(\mathrm{N}=330)\end{array}$ & 17.8 & 9.6 & $-45.6 \%{ }^{* \cdots}$ & 0.75 & 0.70 & $217(65.8 \%)$ & $113(34.2 \%)^{m *}$ \\
\hline & $\begin{array}{l}\text { All } \\
(\mathrm{N}=1305)\end{array}$ & & & & 0.73 & 0.67 & & \\
\hline \multirow{4}{*}{ DAS28-ESR } & $\begin{array}{l}\text { Placebo } \\
(\mathrm{N}=488)\end{array}$ & 6.4 & 5.2 & $-19.2 \%$ & N/A & 0.91 & $441(90.4 \%)$ & $47(9.6 \%)$ \\
\hline & $\begin{array}{l}\text { Baricitinib } \\
\text { (N=487) }\end{array}$ & 6.5 & 3.9 & $-40.0 \% \cdots$ & N/A & 0.86 & $333(68.4 \%)$ & $154(31.6 \%)^{m-m}$ \\
\hline & $\begin{array}{l}\text { Adalimumab } \\
(\mathrm{N}=330)\end{array}$ & 6.4 & 4.0 & $-37.6 \% \cdots$ & N/A & 0.87 & $219(66.4 \%)$ & $111(33.6 \%)^{\cdots *}$ \\
\hline & $\begin{array}{l}\text { All } \\
(\mathrm{N}=1305)\end{array}$ & & & & N/A & 0.90 & & \\
\hline \multirow[t]{4}{*}{ CDAI } & $\begin{array}{l}\text { Placebo } \\
(\mathrm{N}=488)\end{array}$ & 37.6 & 23.4 & $-37.0 \%$ & 0.91 & N/A & $392(80.3 \%)$ & $96(19.7 \%)$ \\
\hline & $\begin{array}{l}\text { Baricitinib } \\
(\mathrm{N}=487)\end{array}$ & 38.1 & 13.0 & $-65.9 \% \cdots \neq$ & 0.86 & N/A & 244 (50.1\%) & $243(49.9 \%)^{\cdots \cdots}$ \\
\hline & $\begin{array}{l}\text { Adalimumab } \\
(\mathrm{N}=330)\end{array}$ & 38.0 & 15.0 & $-60.9 \% *$ & 0.87 & N/A & $173(52.4 \%)$ & $157(47.6 \%)^{\ldots * *}$ \\
\hline & $\begin{array}{l}\text { All } \\
(N=1305)\end{array}$ & & & & 0.90 & N/A & & \\
\hline
\end{tabular}

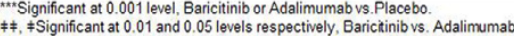

Abbreviations: $C D A=$ Alinical Disease Activity Index; DAS28-ESR=Disease Activity Score 28-erythrocye sedimentation rate $\mathrm{H}$ High=high disease actinity/severity; Low=low disease activity/severity: Mod=moderate
$\mathrm{N}=$ number of patients: RAPID3-like=Routine Assessment of Patient Index Data 3-like.

Conclusions: RAPID3-like documented greater efficacy of baricitinib versus adalimumab and placebo in the RA-BEAM trial, with results in similar ranges to DAS28-ESR and CDAI. RAPID3 is feasible to provide quantitative, standard medical history data; almost of the time and effort is by the patient rather than a health professional, assuring quantitative data in the infrastructure of usual clinical care.
Disclosure of Interest: T. Pincus Shareholder of: Health Report Services, B. Zhu Employee of: Eli Lilly and Company, C. Larmore Employee of: Eli Lilly and Company, J. Bradley Employee of: Eli Lilly and Company, N. Patel Employee of: Eli Lilly and Company, C. Gaich Employee of: Eli Lilly and Company, A. Koch Employee of: Eli Lilly and Company

DOI: 10.1136/annrheumdis-2017-eular.1813

\section{SAT0070 BARICITINIB VERSUS ADALIMUMAB IN PATIENTS WITH ACTIVE RHEUMATOID ARTHRITIS: ANALYSIS OF PATIENTS ACHIEVING A MODERATE EULAR RESPONSE AT WEEK 4}

T.K. Kvien $^{1}$, P. van Riel ${ }^{2}$, A. Rubbert-Roth ${ }^{3}$, R. Blanco ${ }^{4}$, S.S. Liu-Leage ${ }^{5}$, E. Larsson ${ }^{5}$, H. Lund ${ }^{5}$, P. López-Romero ${ }^{5}$, L. Zaremba-Pechmann ${ }^{5}$, P. Emery ${ }^{6}$. ${ }^{1}$ Diakonhjemmet Hospital, Oslo, Norway; ${ }^{2}$ Bernhoven, Uden, Netherlands; ${ }^{3}$ Uniklinik Köln, Köln, Germany; ${ }^{4}$ Hospital Universitario Valdecilla, Santander, Cantabria, Spain; ${ }^{5}$ Eli Lilly and Company, Indianapolis, United States; ${ }^{6}$ Leeds MSK Biomed/Chapel Allerton Hosp, Leeds, United Kingdom

Background: Baricitinib (BARI) is a selective inhibitor of Janus kinase, ${ }^{1}$ improves disease activity in patients (pts) with rheumatoid arthritis (RA), and is associated with inhibition of structural joint damage. ${ }^{2-4}$ Response to BARI observed at week (wk) 4 may be useful to predict future response..$^{5}$

Objectives: To characterise pts with RA who achieved moderate EULAR responses (MERs) ${ }^{6}$ at wk 4 and to describe the outcomes through wk 52 while continuing the assigned treatment.

Methods: Pts enrolled in the RA-BEAM study with active RA who had an inadequate response to methotrexate (MTX) were randomised 3:3:2 to placebo (PBO), BARI $4 \mathrm{mg}$ once daily, or adalimumab (ADA) $40 \mathrm{mg}$ biweekly. ${ }^{1}$ Pts who showed good or no EULAR responses at wk 4 were excluded. For the MER cohort, the cumulative incidence for first transition to good EULAR response and to no EULAR response from wk 4 through wk 52 was estimated in the presence of competing risks events, which either hinder observation of the events of interest or modify the chance that these events occur. ${ }^{7}$ Pts who transitioned from MER to no EULAR response or pts who were rescued or discontinued because of an adverse event or lack of efficacy were counted as no EULAR response; pts who discontinued the study for other reasons (eg, lost to follow-up, death) were censored at the time of discontinuation. No formal statistical tests were performed for these post hoc analyses.

Results: Of 1305 pts who received at least 1 dose of study drug, 683 experienced MERs at wk 4, including 37.3\% (182/488), 62.0\% (302/487), and 60.3\% (199/330) of pts on PBO, BARI, and ADA, respectively. Pts who achieved MERs at wk 4 on $B A R I$ and ADA had similar baseline disease activity characteristics (Table 1). The mean age of the MER subgroup was 53 years, and the mean disease duration was 8.7 years. The mean MTX dosage was $15 \mathrm{mg} / \mathrm{wk}$, and $59 \%$ of pts were taking concomitant oral glucocorticoids. At wk 4, 27\% (131/487) and $11 \%(54 / 487)$ of pts on BARI vs $29 \%(95 / 330)$ and $11 \%(36 / 330)$ of pts on ADA experienced no response or good response, respectively. The cumulative incidence for the first transitions to good EULAR response at wks 12, 24, and 52 was higher in pts who reached MERs at wk 4 on BARI than those on ADA. The cumulative incidence for the first transitions to subsequent no EULAR response was higher in pts who achieved MER at wk 4 on ADA (Figures $1 A$ and 1B, Table 2) than those on BARI. Conclusions: Among pts achieving early MER on BARI and ADA, subsequent loss of response was less common for pts on BARI than for those on ADA. Transitions to good EULAR response were more common for pts who achieved MERs on BARI than for those on ADA. Mechanistic explanations warrant future study.

\begin{tabular}{|c|c|c|c|c|c|c|}
\hline \multicolumn{3}{|c|}{ Characteristic } & \multicolumn{2}{|c|}{$\begin{array}{c}\text { Baricitinib } \\
n=302^{*}\end{array}$} & \multicolumn{2}{|c|}{$\begin{array}{c}\text { Adalimumab } \\
n=199^{*}\end{array}$} \\
\hline \multicolumn{3}{|c|}{$\begin{array}{l}\text { Background therapy } \\
\text { (MTX only), no. (\%) }\end{array}$} & \multicolumn{2}{|c|}{$259(85.8)$} & \multicolumn{2}{|c|}{$173(86.9)$} \\
\hline \multicolumn{3}{|c|}{$\begin{array}{l}\text { Background therapy } \\
\text { (MTX + other cDMARD), no. (\%) }\end{array}$} & \multicolumn{2}{|c|}{$43(14.2)$} & \multicolumn{2}{|c|}{$26(13.1)$} \\
\hline \multirow{2}{*}{\multicolumn{7}{|c|}{ DAS28-ESR category, no. (\%) }} \\
\hline & & & & & & \\
\hline \multicolumn{3}{|c|}{$>3.2$ to $\leq 5.1$} & \multicolumn{2}{|c|}{$12(4.0)$} & \multicolumn{2}{|c|}{$8(4.0)$} \\
\hline & \multicolumn{2}{|c|}{$290(96.0)$} & \multicolumn{2}{|c|}{$191(96.0)$} \\
\hline \multirow{2}{*}{\multicolumn{3}{|c|}{$\begin{array}{l}\text { Baseline mTSS, mean(SD) } \\
\text { HAQ-DI total score, mean (SD) }\end{array}$}} & \multirow{2}{*}{\multicolumn{2}{|c|}{$\begin{array}{l}42.0(50.0) \\
1.6(0.7)\end{array}$}} & \multicolumn{2}{|c|}{$47.1(51.9)$} \\
\hline & & & & & & \\
\hline \multicolumn{7}{|c|}{$\begin{array}{l}\text { Abbreviations: cDlMARD=conventional disease-modifying antirheumatic drug; DAS28-ESR=Disease } \\
\text { Activity Score modified to include the 28-joint count based on the erythrocyte sedimentation rate; } \\
\text { HAQ-DI=Health Assessment Questionnaire-Disability Index; mTSS=modified Total Sharp Score; } \\
\text { MTX=methotrexate. } \\
\text { *501 patients reached moderate EULAR response at week } 4: 302 / 487(62 \%) \text { and } 199 / 330(60 \%) \text { for } \\
\text { BARI and ADA, respectively. }\end{array}$} \\
\hline \multicolumn{7}{|c|}{ Table 2:Time to First Transition to Good and to No EULAR Response (DAS28-ESR) } \\
\hline & \multicolumn{3}{|c|}{ Baricitinib } & \multicolumn{3}{|c|}{ Adalimumab } \\
\hline & $\begin{array}{c}\text { Cumulative } \\
\text { Incidence } \\
(\%)\end{array}$ & \multicolumn{2}{|c|}{${ }_{\text {Lower }}^{95 \%} \mathrm{Cl}_{\text {Upper }}$} & $\begin{array}{c}\text { Cumulative } \\
\text { Incidence } \\
(\%)\end{array}$ & \multicolumn{2}{|c|}{$95 \% \mathrm{Cl}$} \\
\hline \multicolumn{7}{|c|}{ Transition to GoodResponse } \\
\hline Week12 & 18.3 & 14.1 & 22.8 & 15.2 & 10.6 & 20.5 \\
\hline Week 24 & 49.2 & 43.4 & 54.7 & 42.9 & 35.9 & 49.7 \\
\hline Week 52 & 63.6 & 57.8 & 68.8 & 58.1 & 50.9 & 64.7 \\
\hline \multicolumn{7}{|c|}{ Transition to No Response } \\
\hline Week 12 & 8.6 & 5.8 & 12.2 & 13.2 & 8.9 & 18.3 \\
\hline Week 24 & 18.9 & 14.7 & 23.5 & 25.5 & 19.6 & 31.7 \\
\hline Week 52 & 24.2 & 19.5 & 29.2 & 28.9 & 22.7 & 35.4 \\
\hline
\end{tabular}

28-joint count based on the erythrocyte sedimentation rate. 
Figure 1: Time until First transition to Good and No EULAR Response (DAS28-ESR)

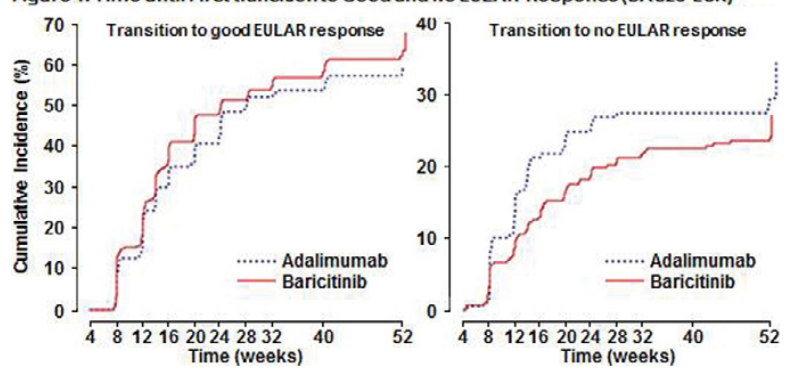

References:

[1] Taylor et el. 2015 ACR Meeting. Abstract 2L.

[2] Dougados M, et al. Ann Rheum Dis. 29 Sep 2016.

[3] Smolen et al. Ann Rheum Dis. 31 Oct 2016.

[4] Fleischmann R et al. Arthritis Rheumatol. 09 Oct 2016.

[5] Kremer et al. 2015 ACR Meeting. Abstract 1050.

[6] Gestel et al. Arthritis Rheum 1996.

[7] Lin G et al. SAS Global Forum 2012

Acknowledgements: Inmaculada de la Torre MD, PhD, Senior Medical Advisor, contributed to this abstract.

Disclosure of Interest: T. K. Kvien Consultant for: AbbVie, Biogen, BMS, Boehringer Ingelheim, Celltrion, Eli Lilly, Epirus, Janssen, Merck-Serono, MSD, Mundipharma, Novartis, Oktal, Orion Pharma, Hospira/Pfizer, Roche, Sandoz, and UCB, Speakers bureau: AbbVie, Biogen, BMS, Boehringer Ingelheim, Celltrion, Eli Lilly, Epirus, Janssen, Merck-Serono, MSD, Mundipharma, Novartis, Oktal, Orion Pharma, Hospira/Pfizer, Roche, Sandoz, and UCB, P. van Riel Consultant for: Eli Lilly and Company, A. Rubbert-Roth Consultant for: Eli Lilly and Company, R. Blanco Consultant for: Eli Lilly and Company, S. S. Liu-Leage Shareholder of: Eli Lilly and Company, Employee of: Eli Lilly and Company, E. Larsson Shareholder of: Eli Lilly and Company, Employee of: Eli Lilly and Company, $\mathrm{H}$. Lund Shareholder of: Eli Lilly and Company, Employee of: Eli Lilly and Company, P. López-Romero Shareholder of: Eli Lilly and Company, Employee of: Eli Lilly and Company, L. Zaremba-Pechmann Shareholder of: Eli Lilly and Company, Employee of: Eli Lilly and Company, P. Emery Consultant for: Pfizer, MSD, Abbvie, BMS, UCB, Roche, Novartis, Samsung, Sandoz, Eli Lilly and Company DOI: 10.1136/annrheumdis-2017-eular.2217

\section{SAT0071 RHEUMATOID ARTHRITIS (RA) REGISTRY IN AKITA PREFECTURE, WHERE AGING IS THE MOST ADVANCED IN JAPAN}

T. Aizawa $^{1}$, T. Kashiwagura ${ }^{2}$, N. Mlyakoshi ${ }^{3}$, Y. Shimada ${ }^{3} .{ }^{1}$ Dept. of Orthopedic Surgery, Kitaakita Municipal Hospital, Kitaakita City; ${ }^{2}$ Akita City Hospita; ${ }^{3}$ Dept. of Orthopedic Surgery, Akita University Graduate School of Medicine, Akita City, Japan

Background: The rate of aging (percentage of population aged 65 years and over) in Akita Prefecture is $33.8 \%$ (26.6\% for the whole of Japan), the highest throughout Japan. The Akita Orthopaedic Group on Rheumatoid Arthritis (AORA) was established in 2010. Since then, patients have been enrolled every year to prepare the registry.

Objectives: To compare patient characteristics as well as clinical effectiveness between the treatments with and without use of methotrexate (MTX) and a biological $(\mathrm{BIO})$ using the data of the AORA registry.

Methods: The subjects were 2,016 patients enrolled in the Akita registry in 2015. The subjects included 403 men and 1,613 women. According to the use of MTX and $\mathrm{BIO}, 2,016$ patients were divided into the group treated with no use of MTX or $\mathrm{BIO}$ (group A), that treated with BIO, but no use of MTX (group B), that treated with MTX, but no use of BIO (group C), and that treated with MTX and BIO (group D).
Results: The subjects were grouped into group A ( $n=673), B(n=153), C \quad(n=805)$, and D ( $n=385)$. MTX was used in $59.0 \%$ and BIO was used in $26.7 \%$ of all patients. The mean ages were 69.6 years (group A), 65.7 years (group B), 65.6 years (group C), and 62.6 years (group D). The aging rates were $67.9 \%$ (group A), $55.6 \%$ (group B), $56.8 \%$ (group C), and $48.3 \%$ (group D), which shows that aging was more advanced in group $A$.

The rates of patients with a complication of hypertension, diabetes, respiratory disease, cerebrovascular disease, heart disease or malignant tumour were $52.0 \%$ (group A), 54.2\% (group B), 45.5\% (group C), and 40.8\% (group D). The incidence of complication was the lowest in group $\mathrm{D}$.

The rates of patients who received one or more of conventional synthetic diseasemodifying antirheumatic drugs (cs DMARDs) other than MTX were $79.0 \%$ (group A), $42.5 \%$ (group B), 39.9\% (group C), and 19.2\% (group D). Although bucillamine and salazosulfapyridine were frequently used in any group, concomitant use of tacrolimus was remarkable in group $\mathrm{A}$ and $\mathrm{C}$, while that of iguratimod was remarkable in groups $C$ and $D$. The rate of use of a prednisolone (PSL), was significantly higher in group $\mathrm{B}$. The dose of PSL was significantly higher in group $\mathrm{A}$. In regard to $\mathrm{BIO}$, three drugs of etanercept, tocilizumab, and abatacept accounted for $90 \%$ in group B. In group D, etanercept and tocilizumab were also frequently used, followed by infliximab, adalimumab, golimumab and abatacept. In DAS28ESR, the rate of combined low disease activity and remission was significantly higher in group $\mathrm{D}$. The mean values of $\mathrm{C}$-reactive protein (CRP) (mg/dL) were 0.61 (group A), 0.52 (group B), 0.47 (group C), and 0.35 (group D), which shows that the mean value was significantly higher in group $A$ than group D. The mean values of matrix metalloproteinase 3 (MMP3) $(\mathrm{ng} / \mathrm{dL})$ were 119.0 (group A), 130.6 (group B), 100.7 (group C), and 88.9 (group D), which shows that the mean value was significantly higher in group $A$ and $B$ than group $C$ and $D$. Conclusions: Using the AORA registry, we compared patient characteristics as well as clinical effectiveness between the treatments with and without use of MTX and BIO. Since in group A, neither MTX nor BIO could be used in most patients, one had to practically rely on PSL. The study suggests that remission needs to be achieved prior to increase in complication due to aging.

References:

[1] Population census in Japan, 2015.

Disclosure of Interest: None declared

DOI: 10.1136/annrheumdis-2017-eular.2560

\section{SAT0072 DOSE REDUCTION OF BARICITINIB IN PATIENTS WITH RHEUMATOID ARTHRITIS ACHIEVING SUSTAINED DISEASE CONTROL: RESULTS OF A PROSPECTIVE STUDY}

T. Takeuchi ${ }^{1}$, M. Genovese ${ }^{2}$, B. Haraoui ${ }^{3}$, L. Xie ${ }^{4}$, R. Klar ${ }^{5}$, A. Luisa Pinto Correia $^{4}$, T. Rooney ${ }^{4}$, S. Otawa ${ }^{4}$, J.S. Smolen $6 .{ }^{1}$ Keio University, Tokyo, Japan; ${ }^{2}$ Stanford University Medical Center, Palo Alto, United States; ${ }^{3}$ Centre Hospitalier de I'Université de Montréal, Montreal, Canada; ${ }^{4}$ Eli Lilly and Company, Indianapolis; ${ }^{5}$ Quintiles IMS Holdings, Inc, Durham, United States; ${ }^{6}$ Medical University of Vienna, Vienna, Austria

Background: In patients (pts) with active rheumatoid arthritis (RA) and inadequate response (IR) to DMARDs, ph3 studies demonstrated efficacy of baricitinib (bari) (2mg and $4 \mathrm{mg}$ ). Larger, more rapid treatment effects were observed for bari $4 \mathrm{mg}$. Objectives: To investigate the effects of bari dose step-down in pts who achieved sustained disease control with bari $4 \mathrm{mg}$.

Methods: Pts with RA who completed a bari ph3 study could enter a long-term extension (LTE) study. In the LTE, pts who received bari $4 \mathrm{mg}$ for $\geq 15$ months and who achieved sustained low disease activity ([LDA]-CDAI score $\leq 10$ ) or remission $(\mathrm{CDAl} \leq 2.8)$ at 2 consecutive visits $\geq 3$ months apart were re-randomised in a blinded manner to continue bari $4 \mathrm{mg}$ or step down to $2 \mathrm{mg}$. Patients could rescue (to bari $4 \mathrm{mg}$ ) if CDAI >10. Efficacy and safety were assessed through 48 weeks (wks) following re-randomisation.

Results: Among pts who achieved sustained disease control with bari $4 \mathrm{mg}$, dose reduction to $2 \mathrm{mg}$ resulted in significant increases in disease activity at 12,24 , and $48 \mathrm{wks}$; however, the majority of pts in both groups maintained the state of LDA

Abstract SAT0072 - Table 1

\begin{tabular}{|c|c|c|c|c|c|c|}
\hline & \multicolumn{6}{|c|}{ Pts originating from RA-BEAM, RA-BUILD, RA-BEACON Combined ${ }^{\dagger}$} \\
\hline & \multicolumn{2}{|c|}{ Week 12} & \multicolumn{2}{|c|}{ Week 24} & \multicolumn{2}{|c|}{ Week 48} \\
\hline & $\begin{array}{c}\text { Continued bari } 4 \mathrm{mg} \\
\mathrm{N}=396\end{array}$ & $\begin{array}{l}\text { Stepped down to bari } 2 \mathrm{mg} \\
\qquad \mathrm{N}=394\end{array}$ & $\begin{array}{l}\text { Continued bari } 4 \mathrm{mg} \\
\qquad \mathrm{N}=353\end{array}$ & $\begin{array}{l}\text { Stepped down to bari } 2 \mathrm{mg} \\
\qquad \mathrm{N}=358\end{array}$ & $\begin{array}{l}\text { Continued bari } 4 \mathrm{mg} \\
\mathrm{N}=245\end{array}$ & $\begin{array}{l}\text { Stepped down to bari } 2 \mathrm{mg} \\
\qquad \mathrm{N}=245\end{array}$ \\
\hline Efficacy measure & \multicolumn{6}{|c|}{ NRI after rescue or for missing data } \\
\hline CDAI LDA $\leq 10$ & $359 / 396(90.7)$ & $326 / 393(83.0)^{\star \star}$ & $309 / 353(87.5)$ & $269 / 357(75.4)^{\star \star \star}$ & 198/245 (80.8) & $167 / 245(68.2)^{\star \star}$ \\
\hline \multirow[t]{2}{*}{ CDAI remission $\leq 2.8$} & $158 / 396(39.9)$ & $143 / 393(36.4)$ & $149 / 353(42.2)$ & $127 / 357(35.6)$ & $99 / 245(40.4)$ & $82 / 245(33.5)$ \\
\hline & \multicolumn{6}{|c|}{ NRI only for missing data (observed data used after rescue) } \\
\hline CDAI LDA $\leq 10$ & $359 / 396(90.7)$ & $326 / 393(83.0)^{\star \star}$ & $314 / 353(89.0)$ & $289 / 357(81.0)^{\star \star}$ & $212 / 245(86.5)$ & $196 / 245(80.0)$ \\
\hline CDAl remission $\leq 2.8$ & 158/396 (39.9) & $143 / 393(36.4)$ & $150 / 353(42.5)$ & $133 / 357(37.3)$ & $103 / 245(42.0)$ & $90 / 245(36.7)$ \\
\hline Safety measure & & & & is $0-48$ & & \\
\hline $\mathrm{n}$ [EAIR/100 PYE] & \multicolumn{3}{|c|}{ Continued bari $4 \mathrm{mg} \mathrm{N}=396$} & \multicolumn{3}{|c|}{ Stepped down to bari $2 \mathrm{mg} \mathrm{N}=394$} \\
\hline SDEAE & \multicolumn{3}{|c|}{$225[70.5]$} & \multicolumn{3}{|c|}{$196[65.4]$} \\
\hline Infection & \multicolumn{3}{|c|}{$99[31.0]$} & \multicolumn{3}{|c|}{$70[23.3]$} \\
\hline SAE & \multirow{2}{*}{\multicolumn{3}{|c|}{$23[7.2]$}} & \multicolumn{3}{|c|}{$23[7.7]$} \\
\hline Serious infection & & & & \multicolumn{3}{|c|}{$4[1.3]$} \\
\hline $\mathrm{AE} \rightarrow$ discontinuation & \multicolumn{2}{|r|}{9 [2.8] } & & \multicolumn{3}{|c|}{$11[3.6]$} \\
\hline
\end{tabular}

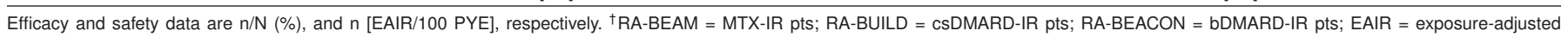
incidence rate; $\mathrm{NRI}=$ nonresponder imputation; $\mathrm{PYE}=$ patient-years of exposure; SDEAE = step-down emergent adverse event. ${ }^{\star \star} \mathrm{p} \leq 0.01,{ }^{{ }^{* *} \mathrm{p}} \leq 0.001 \mathrm{vs}$. continued bari $4 \mathrm{mg}$. 